\title{
Meta
}

Journal des traducteurs

Translators' Journal

\section{Atkins, B. T. S. (Ed.) (1998): Using Dictionaries: Studies of Dictionary Use by Language Learners and Translators, LEXICOGRAFICA Series Mayor 88, 214 pages}

\section{Ioana-Maria Isac}

Volume 46, numéro 3, septembre 2001

URI : https://id.erudit.org/iderudit/003229ar

DOI : https://doi.org/10.7202/003229ar

Aller au sommaire du numéro

Éditeur(s)

Les Presses de l'Université de Montréal

ISSN

0026-0452 (imprimé)

1492-1421 (numérique)

Découvrir la revue

Citer ce compte rendu

Isac, I.-M. (2001). Compte rendu de [Atkins, B. T. S. (Ed.) (1998): Using

Dictionaries: Studies of Dictionary Use by Language Learners and Translators,

LEXICOGRAFICA Series Mayor 88, 214 pages]. Meta, 46(3), 605-606.

https://doi.org/10.7202/003229ar d'utilisation que vous pouvez consulter en ligne.

https://apropos.erudit.org/fr/usagers/politique-dutilisation/ 
Atkins, B. T. S. (Ed.) (1998): Using Dictionaries: Studies of Dictionary Use by Language Learners and Translators, LEXICOGRAFICA Series Mayor 88, 214 pages.

The focal point of the essays in this volume is the activity of dictionary consultation by foreign language learners and translators.

This subtle problem-solving activity involves many factors and all seven pieces of research concentrate on model investigations which should cover as many aspects of the topic as possible.

The complex user-dictionary relationship brings forth two main aspects: on the one hand the need to improve the users' search skills and on the other to improve the elaboration of dictionaries.

The volume opens with an Empirical research on dictionary use in foreign language learning: survey and discussion by Jan. H. Hulstin \& B.T. Sue Atkins. The paper gives an insight into the cognitive processes involved in using a dictionary. The research design has as objective to set the scene for a new generation of electronic dictionaries, optimally customizable by users according to their look-up habits and linguistic needs.

The second paper, Language Learners Using dictionaries: The Final Report on the EURALEX/AILA Research Project on Dictionary Use by B.T. Sue Atkins \& Krista Varantola attempts in a wide-ranging presentation to link the profile of the dictionary users (over one thousand language-learning students in four European language areas) with their effective use of dictionaries. The authors make a full account of the methodology used to elicit the valid results recorded, for the benefit of the readers who may wish to replicate the tests, and adapt them to serve their own interests.

In the third paper, Monitoring Dictionary Use by B.T. Sue Atkins \& Krista Varantola the goal is to find out what people actually do when they consult their dictionary for help with a translation. The resultant database of the experiment is a useful source of information both for lexicographers and for language teachers.

In An Empirical Study of Dictionary Use in L2-L1 Translation, by Kristen McIntosh, the purpose of the study was to gather information on how student translators use dictionaries (L2-L1 translation) and to see what effects certain aspects of dictionaries have on them (e.g. the language used in dictionary definitions). The direct observation method was preferred for the tests, supplemented with a think-aloud protocol.

What type of word do language learners look up? by Paul Bogaards is the following essay in which the author conducted a small-scale study to shed some light on why language learners look up some types of words and not others and if they do this in a systematic way or haphazardly.

The paper Defining a Shoehorn: the Success of Learner's Dictionary Entries for Concrete Nouns by Hialry Nesi, investigates learner's perceptions and interpretations of definitions from major learners' dictionaries. The findings suggest that differences in the wording of entries can make a significant difference to the success of dictionary look up.

The last essay, The Translator and the Dictionary: Beyond Words? by Margaret Rogers \& Khurshid Ahmad, discusses some ways in which the concept of dictionary, facilitated by recent development in computing and corpus linguistics, may be accommodated in order to better serve translators' needs. A perspective is considered in particular: the use by translators of corpus-processing tools in order to solve relations 
between word forms and to identify patterns which may not be evident in traditional dictionary entries.

The papers in the LEXICOGRAPHICA Series Mayor 88 volume represent a highly valuable contribution to the field of dictionary use, because anyone confronted with a linguistic difficulty, be it in production, reception or translation, may feel it worthwhile to consult some type of dictionary.

IOANA-MARIA IsAC

Montréal, Canada 